\title{
高校教师如何践行“课程思政”理念 落实立德树人根本任务
}

\section{How to Practice the Idea of "Ideological and Political Theories Teaching in All Courses" and} Implement the Basic Task of Building a Person by virtue

\section{聂晓微}

Xiaowei Nie

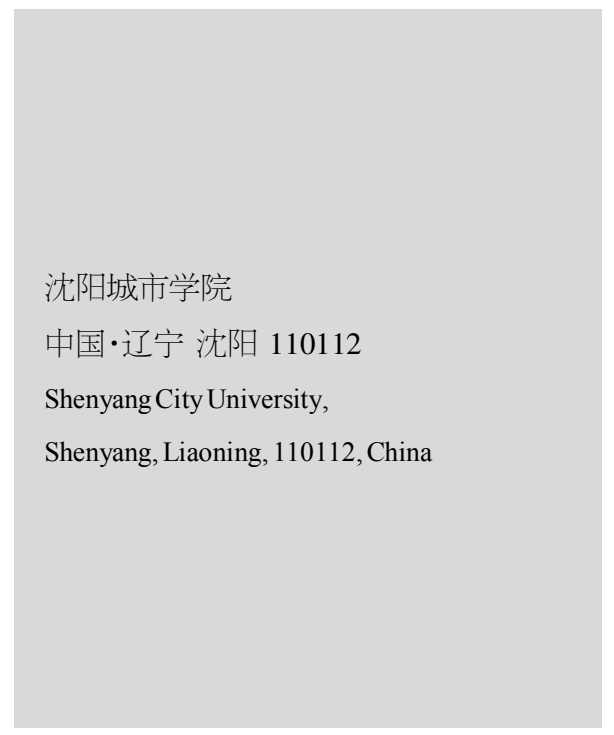

【摘要】论文通过学习习近平总书记关于教育的重要论述,针对“课程思政”的教育内容 设计,结合习近平总书记的系列讲话、遵循新时代高等教育的规律,提出开展课程思政的意 义与作用、课程思政的建设目标与内容、课程思政的设计要求与方法等方面内容进行探讨。

【Abstract】Through studying General Secretary Xi Jinping's important exposition on education, this paper aims at the educational content design of "Ideological and Political Theories Teaching in All Courses", combining with General Secretary Xi Jinping's series of speeches and following the law of higher education in the new era, puts forward the significance and function of carrying out Ideological and Political Theories Teaching in All Courses, the construction goal and content and the design requirements and methods of curriculum ideological and political.

【关键词】课程思政;立德树人;建设内容;五大方法

【Keywords】Ideological and Political Theories Teaching in All Courses; building a person by virtue; construction content; five methods

【DOI】10.36012/sde.v2i3.1596

\section{1 引言}

理念践行是“课程思政”的核心,立德树人是“课程思政” 的根本,全员育人是“课程思政”的基本保障。提高课程思政认 识,加强课程思政建设, 是摆在每一名教师面前的一个重要任 务和研究课题。习近平总书记在全国高校思想政治工作会议上 指出: “要坚持把立德树人作为中心环节,把思想政治工作贯穿 教育教学全过程,实现全程育人、全方位育人,努力开创中国高 等教育事业发展新局面。”

\section{2 开展课程思政的意义与作用}

\section{1 课程思政是培养社会主义事业建设者和接}

\section{班人的基础手段}

学生的天职是学习,完成学业指的就是完成各类课程的 学习任务,学校的育人过程也必然寓于在学校的课堂教学和 学生的课程学习过程中 ${ }^{[1]}$ 。在课堂教学中, 可以通过一定的过 程和方法, 让学生通过知识技能的学习, 进而潜移默化地建 立情感态度和价值观, 实现知识传授、能力培养和价值引领
的统一。

\section{2 课程思政是全员、全过程、全方位育人的重} 要体现

所有课程都有育人功能,各门课都要守好一段渠、种好责 任田。要把做人做事的基本道理,把社会主义核心价值观的要 求,把实现民族振兴的理想和责任融入各类课程教学之中,形 成协同效应 ${ }^{[2]}$ 。做到所有课堂都是育人主渠道,课程门门有思 政,教师人人讲育人。

\section{3 课程思政是学校落实立德树人根本任务的} \section{主要载体}

教师是立德树人的主力军。“师者,所以传道、授业、解惑 者也”, 学高为师身正为范。教师个人之学术造诣、人格魅力和 高尚品格,对学生具有巨大的引领和示范作用。教师在课上课 下乃至学生面前的一言一行、在教学中对学生的关爱、严格要 求与管理、在答疑解惑中为学生树立正确的人生观和价值观 等。只有切实做好课程思政,才能真正实现教师以德立身、以 德立学、以德施教。 


\section{3 课程思政建设的内涵与内容}

\section{1 课程思政建设的内涵}

课程思政是一种教育理念, 不是一门或一类特定的课程, 而是学校所有课程都具有传授知识培养能力及思想政治教育 双重功能。所有课堂都是育人主渠道, 课程门门有思政,教师 人人讲育人。

课程思政是一种教学思维方式, 要求教师在教学过程中要 有意、有机、有效地对学生进行思想政治教育; 体现在教学思维 和课程设计上,要对专业课的内容、方法重新挖掘、运用德育的 思维视角,提炼专业课程中蕴含的思想政治教育元素, 在“润物 细无声”的专业知识学习中融入理想信念层面的精神指引。

课程思政不是要改变专业课程的本来属性, 不是要把思 政课的内容简单照搬到专业课程中去, 更不是要把专业课改 造成思政课模式或者将所有课程都当作思政课程。课程思政 本身具有相对的独立性、教师的自主性，不存在自身的体系， 也不需要和其他课程的课程思政相互衔接。

\section{2 课程思政建设的内容}

\section{2 .1 注重师德风范引领}

学高为师, 身正为范。教师要坚持教育者先受教育, 努力 成为先进思想文化的传播者、党执政的坚定支持者, 更好担起 学生健康成长指导者和引路人的责任。以德立身、以德立学、 以德施教,为学生点亮理想的灯、照亮前行的路。

\section{2 .2 注重引导学生如何做人}

在传授专业知识的过程中, 要结合专业产业领域和未来 职业社会环境,注重对学生个人品格的培养,教会学生如何做 人。内容包括培养社会道德、个人道德、职业道德、人文素养、 正确的三观等道德情操,健全思想、情感、态度、行为、心理、哲 学、艺术、性格、体质等人格特质, 提升观察、想象、思考、判 断、推理、逻辑, 思维等智力要素。

\subsection{3 注重指导学生如何做事}

要结合专业教育, 挖掘知识中所蕴含的哲学思想和科学 方法, 帮助学生建立科学的思维模式和行为方式, 指导学生学 习与工作,学会如何做事。内容包括:认识论和方法论、求真务 实、开拓进取、钻研、毅力、勤奋、视野、批判性思维、创新意 识、学术诚信等。

\section{2 .4 注重核心价值观教育}

教师要在课程教学过程中，将社会主义核心价值观的基 本内涵、主要内容等有机、有效地纳入整体教学布局和课程安 排,做到专业教育和核心价值观教育相融共进。引导学生做社 会主义核心价值观的坚定信仰者、模范践行者。内容包括:家 国情怀、党和国家意识、社会主义核心价值观、民族精神和时
代精神、优秀中华传统文化的认同和坚守等。

\section{4 课程思政设计五大方法}

\section{1 树立课程思政意识, 把提升教书育人责任放}

\section{到首位}

教师要树立课程思政的理念, 提高教师的政治站位。充分 认识做好课程思政是高校实现立德树人根本任务的必要途 径, 牢固确立每门课程都具有育人功能和每位教师都肩负育 人责任的担当意识,树立课程思政意识。专业课教师围绕落实 立德树人这一根本任务,把教书和育人结合起来。

\section{2 深入挖掘课程蕴含的思政要素,保证四个突出}

各门课程都蕴含着丰富的思想政治教育元素，根据不同 课程的性质特点, 把握好所要挖掘拓展的重点。课程要突出价 值引导和优秀传统文化的传承, 不断增强“四个自信”; 突出培 育学生科学精神、创新精神, 明确人类共同发展进步的历史担 当。要突出培育学生求真务实、实践创新、精益求精的工匠精 神; 突出培育高尚的文化素养、乐观的生活态度, 注重把爱国 主义情怀渗透到课程教学中, 帮助学生树立民族自信。

\section{3 优化课程设计和课堂教学, 实现育人效果最} 大化

秉承“课程承载思政”和“思政寓于课程”的理念, 优化课 程设计, 根据不同专业课程特色, 合理嵌入育人要素。制定与 课程相关的学习要求、规范、仪式、考核标准等,充分发挥课堂 教学的主渠道作用, 以润物无声的形式将正确的价值观传导 给学生, 实现育人效果最大化。

\section{4 拓展教学时间和空间,形成线上线下联动效应}

以课程为平台, 注重促进课堂内外联动, 充分利用校外实 践教学基地和网上教学资源, 将课程教学与小组学习、专业实 践、社会实践相结合,线上线下联合互动, 提升课程思政教育 的引领力,形成课程整体育人的联动效应。

\section{5 突出问题导向, 在落细落小落实上下功夫}

课程思政教育要突出问题导向, 切口要小, 从细小处人 手, 以小见大。一要结合学生关注的社会热点, 从专业的角度 阐明道理, 提升学生的价值判断和理性思维; 二要从被学生忽 视的身边重要问题人手, 通过专业解读其价值和意义; 三要从 行业专业领域问题切入, 通过多维度分析影响其心理与情感。

\section{参考文献}

[1]王晶.对师范平台课《现代教育技术》课程思政建设的探讨 [J]. 中国校外教育,2018(35):106-107.

[2]李菊英,颜州.获得感: 思想政治理论课实效性的重要生成要素 [J].思想理论教育导刊,2018(1):5. 